Cells

Tissues

Organs

Addison, W.N. 176

Ameye, L. 136

Boskey, A.L. 144

Carlson, A.E. 166

Embree, M. 136

Feng, J.Q. 241

Fong, H. 248

Foster, B.L. 248

Franceschi, R.T. 166

Fukumoto, S. 189

George, A. 232

Gibson, C.W. 196

Goldberg, M. 202

Gopalakrishnan, R. 166

Hao, J. 232
Holmbeck, K. 154

Hu, J.C.-C. 219

Kaartinen, M.T. 176

Kilts, T. 144

Krebsbach, P.H. 125, 219

Kulkarni, A.B. 196

Lu, Y. 241

McKee, M.D. 176

Moradian-Oldak, J. 202

Nonaka, K. 189

Opperman, L.A. 127

Pi, Y. 241

Popowics, T. 248

Rawlins, J.T. 127

Simmer, J.P. 219
Somerman, M.J. 248

Suttamanatwong, S. 166

Swanson, E.C. 248

Verdelis, K. 144

Wadhwa, S. 136

Wright, J.T. 196

Xie, Y. 241

Yamada, A. 189

Yamada, Y. 189

Yamakoshi, F. 219

Yamakoshi, Y. 219

Young, M.F. 125, 136, 144

Zhang, S. 241

\title{
Subject Index Vol. 181, No. 3-4, 2005
}

Ameloblastin 189, 219

Amelogenesis imperfecta 196

Amelogenin(s) 189, 196, 202, 219, 248

Apatite 202

Arhgap6 196

Biglycan 136

Biglycan-knockout mice 144

Biomineralization 176, 202

Bone morphogenetic protein 248

- remodeling 176

Cartilage remodeling 154

Cementum 248

Collagenase 154

Cranial sutures 127

Craniofacial morphogenesis 154

Craniosynostosis 127

Dentin matrix protein 1241

- mineralization 232

- sialophosphoprotein gene 219
Enamel 202

- matrix protein 189

- proteins 196

Enamelin 219

Extracellular matrix 127, 176, 232

Fibromodulin 136

Fourier transform infrared microspectroscopy 144

Hydroxyapatite 144

Intramembranous bone growth 127

Kallikrein 4219

Macromolecular assembly 202

Matrix Gla protein 166

- metalloproteinase 20219

Membrane type 1 matrix metalloproteinase 154

Micro-computed tomography 144

Mineralization 144, 166
Nested genes 196

Osteoarthritis 136

Osteoblast 166

Osteogenesis 176

Osteopontin 166, 176

Parathyroid hormone 166

Periodontium 248

Phosphophoryn 232

Proteoglcyans 136

Temporomandibular joint 136

Tooth development 241

Transgenic mice 241

Type I collagen fibrillogenesis 232

Vascular calcification 166 